\title{
局部的水素脆性に基づく $\mathrm{SCC}$ 裂進展の \\ 破壊力学的考察
}

\author{
大西 忠一*・東＼cjkstart健司*
}

Application of fracture mechanics to propagation of stress corrosion

crack based on localized hydrogen embrittlement

UDC: 669.71 '721: 620. 194

Tadakazu OHNISHI* and Kenji HIGASHI*

In order to estimate quantitatively and theoretically, the $\mathrm{SCC}$ test results for $\mathrm{Al}-8 \% \mathrm{Mg}$ alloy were analyzed with applying the fracture mechanics, based on the presumption that the principal determining parameter in SCC is the localized hydrogen embrittlement at near the crack tip. Theoretically, the high hydrogen concentration is appeared to be unable to produce through the hydrostatic stress induced diffusion only, in the case of lower yield strength materials such as one discussed here. Thus the concentration due to the increase of plastic strain was discussed by the strain field analysis, assumed that the hydrogen content at near the crack tip can increase proportionally with an increase in dislocation density associated with the plastic yielding within the plastic zone. Results of analysis for the moving crack with continuous hydrogen supply from an environment, showed that the extremely high concentration can be induced within the plastic zone, and that the theoretical prediction can be very closely consistent with the actual behavior of the alloy discussed. Nucleation and propagation of SCC crack were also considered with the fracure mechanics.

(Received March 15, 1984)

\section{1. 緒言}

アルミニウム合金の応力腐食割れ (SCC) 発生機構に 関しては，古くから指摘されているアノード溶解の寄与 とともに，最近水素脆性（HE）の寄与が強い関心を集 めている1”。筆者らも $\mathrm{Al}-8 \% \mathrm{Mg}$ 合金を素材にした研 究により，この合金の SCC がき裂先端に形成された局 部的 $\mathrm{HE}$ 領域内での脆性き裂発生に基づく現象である

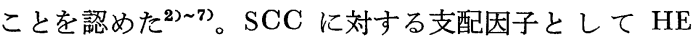
を考える観点に立てば，SCC き裂先端における水素 集 積とそれによる局部的脆化がどのようにして生じるかが 最も重要である。SCC き裂の前方が局部的に HE を起 こしていることは先行水素脆化域 (HEZ) を生じること や, HEZ 前方のストレッチ・ゾーン (SZ) が 小さくて 局部的勒性值の低下が認められることなどより分か

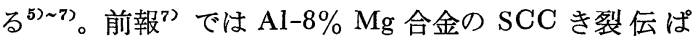
特性と $\mathrm{HEZ}$ や SZ の変化との関倸を調べ，これらが破
壊の発生に及ぼす水素の影響として説明できることを明 らかにした。しかし，これらの関係を定量化し，破壊機 構と結びつけるにはき裂先端に形成される水素濃度分布 を知ることが必要になる。

本報は，SCC き裂先端に生じる水素濃度分布をそこ での応力，ひずみ場との関係で考察し，これに基づいて 前報で示した関係 (Fig. 1) 7) を定量的に説明し，併せ て SCC き裂の発生, 伝ぱ機構を破壊力学的に説明する ことを試みたものである。解析に使用したデータは Al$8 \% \mathrm{Mg}$ 合金のもので，その 主な材料特性 は Table 1 に示している。この材料の機械的性質や SCC 特性, HE 特性などの詳細については筆者らの既報2) 12) を参 照さ れたい。

\section{SCG き裂先端での水素濃度分布}

\section{1 応力場による水素集積}

$\mathrm{SCC}$ 環境中において水素浸透が生じ, き裂先端近 傍

* 大阪府立大学工学部 (堺市)。Faculty of Engineering, University of Osaka Prefecture. (Sakai) 
Table 1 Tensile properties and fracture toughness values of the specimen.

\begin{tabular}{|c|c|c|c|c|c|c|c|c|}
\hline \multirow{2}{*}{\multicolumn{3}{|c|}{ tensile properties }} & \multirow{2}{*}{\multicolumn{2}{|c|}{$\begin{array}{c}\text { flow curve } \\
\sigma=\sigma_{0} \varepsilon^{n}\end{array}$}} & \multirow{3}{*}{$\begin{array}{c}\text { grain } \\
\text { size } \\
(\mu)\end{array}$} & \multicolumn{3}{|c|}{ fracture toughness } \\
\hline & & & & & & \multirow{2}{*}{$\underset{(\mu)}{S Z W_{c}}$} & \multirow{2}{*}{$\begin{array}{c}C T O D_{c} \\
(\mu)\end{array}$} & \multirow{2}{*}{$\begin{array}{c}K_{I C} \\
\left(\mathrm{~kg} / \mathrm{mm}^{3 / 2}\right)\end{array}$} \\
\hline$\sigma_{B}\left(\mathrm{~kg} / \mathrm{mm}^{2}\right)$ & $\sigma_{y s}\left(\mathrm{~kg} / \mathrm{mm}^{2}\right)$ & $\delta(\%)$ & $\sigma_{0}$ & $n$ & & & & \\
\hline 30.4 & 13.8 & 29.6 & 41.3 & 0.218 & 80 & 200 & 267 & 244 \\
\hline
\end{tabular}

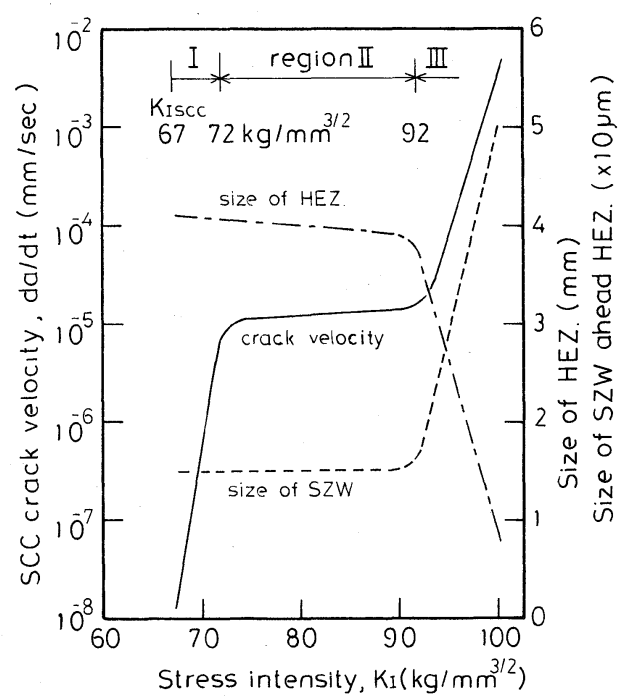

Fig. 1 SCC crack growth rate and sizes of HEZ and SZW as a function of stress intensity, for Al$8 \% \mathrm{Mg}$ alloy aged at $200^{\circ} \mathrm{C}$ for 1 hour, in $3.5 \%$

$\mathrm{NaCl}$ aqueous solution. (after Ohnishi ${ }^{7}$ )

に高い水素集積の生じているらしいことは定性的ながら

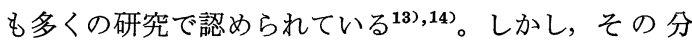
布状態については必ずしも明らかではなく, 定量化の試

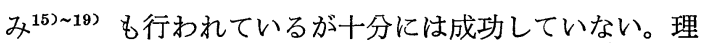
論的に定量化する試みの多くはき裂先端に生じる応力場 に基づいた水素の誘起拡散を考えており, これは弾性応 力の存在が水素の化学ポテンシャルを変化させ, そのた めに水素の誘起拡散が生じるという Oriani ${ }^{15)}$ の考えを 基礎にしている。

この理論によれば弾性応力の存在下における水素濃度 の変化は(1)式で表すことができる ${ }^{15}$ 。

$$
R T \ln C / C_{0}=V_{H} P_{h}
$$

ここで $R$ : 気体定数, $T$ : 絶対温度, $C_{0}$ : 初期平均水素 濃度, $C$ : 応力場での水素濃度, $V_{\boldsymbol{H}}$ : 水素の 部分モル体 積, $P_{h}$ : 静水圧応力である。たとえば, 刃状転位の作る 応力場を考えるとすると, その静水圧応力場は(2)式で表 される。

$$
P_{h}=G b / 2 \pi(1-v) x
$$

ここで $G:$ 剛性率, $b:$ バーガースベクトル, $v:$ ポアソ ン比， $x$ : 転位芯からの距離である。いま, アルミニウ ム合金に対する值として $R=850 \mathrm{~kg} \cdot \mathrm{mm} / \mathrm{g}$-atom K,
$T=300 \mathrm{~K}, V_{H}=1.7 \times 10^{3} \mathrm{~mm}^{3} / \mathrm{g}$-atom $\left.* 1\right), G=2,700 \mathrm{~kg} /$ $\mathrm{mm}^{2}, \nu=0.33$ 用いるとすれば，(1)(2)式より $x=b$ 亿お ける濃度比は $C / C_{0} \doteqdot 90$ となる。これは転位が水素の卜 ラップ源として有効に㗢くことを示している。

同様の解析をき裂先端の応力場に適用することも行わ れている ${ }^{18), 199}$ 。弾性破壊力学によれば, き裂先端に生 じる静水圧応力場は平面ひずみ状態で

$$
P_{h}=\frac{1}{3}\left(\sigma_{x}+\sigma_{y}+\sigma_{z}\right)=\frac{2}{3}(1+v) K_{\mathbf{I}}(2 \pi x)^{-1 / 2}
$$

と表される。ここで $\sigma_{x}, \sigma_{y}, \sigma_{z}: x, y, z$ 方向の応力, $K_{\mathrm{I}}$ : モード $\mathrm{I}$ の破壊勒性值, $x$ : き裂先端からの距離で ある。(3)式を(1)式に代入すれば， $x \rightarrow 0$ で $P_{h} \rightarrow \infty$ である から, $C / C_{0} \rightarrow \infty$ となり, き裂先端では無限に高い水素集 積を生じることになる。しかし実際には, き裂先端の応 力集中によつて塑性降伏が生じるため, 生じる最大応力 は有限である。最大応力は Rice ら ${ }^{211}$ につて示された 加工硬化を考慮した弾塑性応力場でも, 約 $5 \sigma_{y s}$ (加工 硬化指数 $n=0.2$ 場合, $\sigma_{y s}$ ：降伏応力）を越えることは ない。そこで, $P_{h}=5 \sigma_{y s}, \sigma_{y s}=13.8 \mathrm{~kg} / \mathrm{mm}^{2}$ とすると(1) 式より $C / C_{0} \doteqdot 1.6$ となる。これは $\sigma_{y s}$ の大きな材料では 応力場による高い水素集積が生じても， $\sigma_{y s}$ の小さな材 料では応力場による誘起拡散が大した水素集積を生じな いことを意味している。しかしながら，実際にはこのよ らな低い值ではなくもつと高い水素集積を生じているで あろらことは定性的な実験結果 ${ }^{13), 14)}$ からも容易に推定 しうる。したがって, 水素集積を生じる別の機構を考兄 る必要がある。

\section{2 ひずみ場による水素集積}

Riceら ${ }^{211}$ によつて考察された弾塑性理論によれば，き 裂先端ではその距離 $R_{x}$ が,

$$
R_{x}=0.032\left(K_{\mathbf{l}} / \sigma_{y s}\right)^{2}
$$

で表される塑性域が形成されている。さらに，き裂先端 近傍には $\mathrm{D}$ 領域と称される寸法 $D_{x}$ が，

$$
D_{x} \doteqdot 2 C T O D
$$

で表される高ひずみの集積した非線形領域が 生じてお り，き裂の発生，伝ぱと密接に関係していると考えられ

${ }^{* 1} \mathrm{Al}$ 中の $\mathrm{H}$ の部分モル使積 $V_{H}$ はよく分かってい ない。多くの金属に詨しては固溶 $\mathrm{H}$ の体積がほぼ $2.9 \AA^{3}$ 一定である ${ }^{20)}$ といわれているので，これより 算出した。 


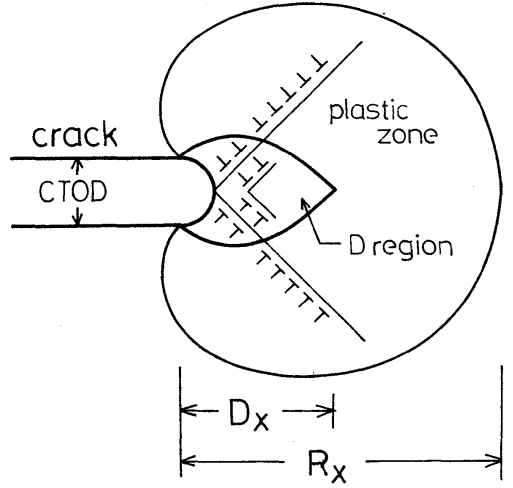

Fig. 2 Elastic-plastic stress-strain field for a blunting crack tip deforming. (after Rice-21))

ている21,22) (Fig. 2)。ただし，CTOD はき裂先端開口 変位である。塑性域はき裂先端での高い応力集中により 局部的な塑性降伏が生じて形成されるものであるから， この領域内ではすべり系の活動により転位などの欠陥密 度が著しく増大している。前述したように転位は水素の よいトラップ源として働くから，SCC 環境中より 供 給 された水素は転位にトラップされてき裂先端近傍に留ま り，集積することが考えられる。この場合にはき裂先端 での塑性ひずみ分布を知ることが必要である。

Rice ら ${ }^{23}$ によればき裂先端での 塑性ひずみ $\varepsilon_{x}^{p l}$ の分 布は

$$
\varepsilon_{x}^{p l}=\left(J / \sigma_{0} I_{n}\right)^{1 / n+1}\left(1 / x^{1 / n+1}\right) \tilde{\varepsilon}^{p l}
$$

で表される。ただし $J: J$ 積分， $\sigma_{0}$ : 応力一ひずみの関 係に対する Ramberg-Osgood の関係式 $\sigma=\sigma_{0} \varepsilon^{n}$ で与えら れる係数, In: $n$ に依存した定数で，その值は $\mathrm{Shih}^{24)}$ に よつて与えられている， $\tilde{\varepsilon}^{p l}$ : き裂先端の特異ひずみ場の 分布を与える関数である。平面ひずみ状態では

$$
J=K_{\mathrm{r}}{ }^{2}\left(1-v^{2}\right) / E
$$

であるから ( $E$ : ヤング率), (6)式は次のように書ける。 $\left.\varepsilon_{x}^{p l}=\left\{\sigma_{y s}{ }^{2}\left(1-v^{2}\right) / \sigma_{0} I_{n} E\right\}^{1 / n+1} \tilde{\varepsilon}^{p l}\left\{K_{\mathrm{I}} / \sigma_{y s}\right)^{2} / x\right\}^{1 / n+1}$

一方， $\tilde{\varepsilon}^{p l}$ は全ひずみ理論より

$$
\left(\varepsilon_{e q}^{p l}\right)^{2}=\frac{2}{9}\left\{\left(\varepsilon_{x}^{p l}-\varepsilon_{y}^{p l}\right)^{2}+\left(\varepsilon_{y}^{p l}-\varepsilon_{z}^{p l}\right)^{2}+\left(\varepsilon_{z}^{p l}-\varepsilon_{x}^{p l}\right)^{2}\right\}
$$

で与えられる。ここで $\varepsilon_{e g}^{p l}:$ 相当塑性ひずみ, $\varepsilon_{x, y, z}^{p l}: x$, $y, z$ 方向の塑性ひずみである。平面ひずみと小規 模降 伏を仮定すると $\varepsilon_{z}^{p l}=0 ， \varepsilon_{x}^{p l}=-\varepsilon_{y}^{p l}$ であるから，

$$
\varepsilon_{x}^{p l}=\frac{\sqrt{3}}{2} \varepsilon_{e q}^{p l}
$$

となる。そこで弾塑性境界において $\varepsilon_{e q}^{p l}$ が降伏ひずみ $0.2 \%$ 等しいとすると，(10)式より $\varepsilon_{x}^{p l}=0.173 \%$ をら る。弾塑性境界の位置は(4)式で与えられるので, $x=R_{x}$
とし $, \sigma_{y s}=13.8 \mathrm{~kg} / \mathrm{mm}^{2}, \quad v=0.33, \sigma_{0}=41.3 \mathrm{~kg} / \mathrm{mm}^{2}$, $I_{n}=5.07, E=7200 \mathrm{~kg} / \mathrm{mm}^{2}, n=0.218, \quad \varepsilon_{x}^{p l}=0.173 \%$ と すると，(4)(8)式より $\tilde{\varepsilon}^{p l}=17.9 \%$ となる。ゆえに，これ らの数值を用いることによって(8)式は最終的に

$$
\varepsilon_{x}^{p l}=1.38 \times 10^{-4}\left(K_{I}^{2} / x\right)^{0.821}
$$

と表せる。最大ひずみは(10)式において $\varepsilon_{e q(\max )}^{p l}=29.6 \%$ と することで $\varepsilon_{x}^{p l}{ }_{(\max )}=25.6 \%$ をう。この最大ひずみを 生じる位置は(11)式で求まる。

次に，転位密度 $N$ は塑性ひずみ $\varepsilon_{x}^{p l}$ （\%表示とする） と比例的な関係にあり，一般に次のような関係として表 すことができる。

$$
N=N_{0}+\alpha \varepsilon_{x}^{p l}
$$

ここで $N_{0}$ : 初期転位密度, $\alpha$ : 実験定数, である。そこ で，転位にトラップされて集積する水素濃度比 $C / C_{0}$ が 転位密度の増加に比例すると仮定すれば，

$$
C / C_{0}=A\left(N / N_{0}\right)=A\left(1+\alpha \varepsilon_{x}^{p l} / N_{0}\right)
$$

と表せる。比例定数 $\mathrm{A}$ は，初期平均濃度において転位が 水素により飽和しているとは考えられないから，トラッ プに伴ら単位転位線当りの濃度増加を考慮すれば $A \geqq 1$ と考えてよいであろう。ごく一般的な関係として，十分 焼きなまされた材料の転位密度は $10^{8} / \mathrm{cm}^{2}$ 程度，1\%塑 性ひずみで $10^{8 \sim 10} / \mathrm{cm}^{2}, 10 \%$ 塑性ひずみで $10^{9 \sim 11} / \mathrm{cm}^{2}$ 程 度とされている ${ }^{25)}$ ので, 仮に $N_{0}=10^{8}, \alpha \doteqdot 10^{9}$ とし, 定数 $A$ を控え目に見積って $A=1$ とすれば, 濃度比 $C / C_{0}$ は (11)(13)式より

$$
C / C_{0}=1+1.38 \times 10^{-3}\left(K_{\mathbf{I}}^{2} / x\right)^{0.821}
$$

となる。最大水素濃度 $C_{\max }$ は最大ひずみ $\varepsilon_{x}^{p l}{ }_{\text {(max) }}=25.6$ $\%$ に扔ける濃度として与えられるので, $C_{\max } / C_{0}=257$ と なる。き裂先端には高い水素集積の生じることが 分か る。(14)式の表わす分布は $K_{\mathrm{I}}$ のいくつかの值について Fig. 3 に示している。ただし, 最大ひずみを生じる位置 の内側は飽和状態にあるとしている。

\section{3 移動き裂前方への拡散}

$\mathrm{SCC}$ き裂先端の塑性ひずみによつて誘起される水素 集積は，SCC 環境中より供給された水素が塑性域 内 で 活動する転位によつてトラップされることのみによつて 決まるとすれば(14)式で表される。しかし実際には，水 素を発生する化学反応がき裂先端では連続的に続いてい るので，き裂先端で達せられる高い水素濃度ポテンシャ ルを駆動力とした通常の体積拡散を考慮する必要がある であろら。さらに，SCC においてはき裂が前進を続け ている。

このよらな移動き裂前方への水素拡散は Johnson ${ }^{17)}$ に よつて取り扱われている。拡散の表現には移動線熱源前 方への熱伝導の解析式 ${ }^{26)}$ が適用できる。すなわち, 移動 き裂前方の水素濃度 $C$ は

$$
C=\beta \exp \{-(d a / d t) x / 2 D\} K_{0}\{(d a / d t) x / 2 D\}
$$




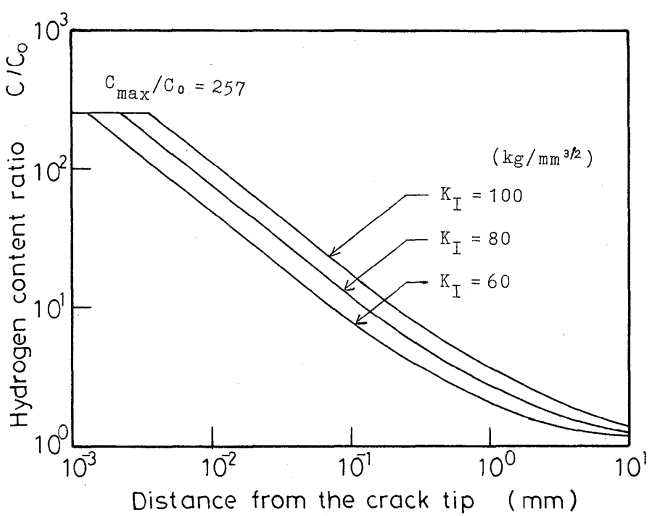

Fig. 3 Hydrogen concentration profiles ahead of crack, calculated from eq. (14).

と表される。ここで $\beta$ : 係数, $D$ : 水素の 拡 散 係数, $K_{0}: 0$ 次の修正第 2 種ベッセル関数である。未知の係数 $\beta$ を消去するために, 初期濃度 $C_{\max }$ は $x=x_{0}$ における 濃度 $C_{\left(x_{0}\right)}$ でで与えられるとし， $x_{0}$ を(11) 式で求められ る最大水素濃度を生じる位置とすれば,

$$
\begin{aligned}
& C / C_{\text {max }}= \frac{\exp \{-(d a / d t) x / 2 D\} K_{0}\{(d a / d t) x / 2 D\}}{\exp \left\{-(d a / d t) x_{0} / 2 D\right\} K_{0}\left\{(d a / d t) x_{0} / 2 D\right\}} \\
&= \frac{\exp \{-(d a / d t) x / 2 D\} K_{0}\{(d a / d t) x / 2 D\}}{\exp \left\{-(d a / d t) e^{-14.8} K_{\mathrm{I}}^{2} / 2 D\right\}} \\
& K_{0}\left\{(d a / d t) e^{-14.8} K_{\mathbf{I}} / 2 D\right\}
\end{aligned}
$$

となる。(16)式で表されるき裂前方の水素濃 度 分布は $(d a / d t) / D$ と $K_{\mathbf{I}}$ 值とに依存して変化し，その様子は Fig. 4 に示したようになる。ただし, $D=4 \times 10^{-5} \mathrm{~mm}^{2} /$ $\sec ^{11)}$ としている。 $K_{\mathrm{I}}$ が同じであれば $d a / d t$ の值によつ て分布は大きく変化し, $d a / d t$ の小さいときはき裂前方 の非常に広い範囲にわたつて高い水素集積を生じるが, $d a / d t$ が大きくなると急速に減衰する。一方, $d a / d t$ が同 ビであれば $K_{\mathrm{I}}$ 值によつて分布は変化するが，その程度 は小さく水素集積の範囲はほとんど変化しない。

\section{3. き裂核の発生と HEZ の形成}

SCC き裂先端での水素濃度分布は Fig. 4 に示したよ らに $d a / d t$ と $K_{\mathrm{I}}$ によつて変化する。そこで, Fig. 1 に 示したよらな挙動をする $\mathrm{Al}-8 \% \mathrm{Mg}$ 合金について，実 際の挙動範囲で生じていると思われる分布を示すと Fig. 5 のようになる。ただし，(16)式に従つた分布をとるの は塑性域 $R_{x}$ 内に限られ，その外側では急速に低下する としている。これは, 塑性域内では転位の活動により水 素が十分かつ速やかに輸送されトラップされるであろう が，塑性域外では輸送手段を欠き，弾性応力による誘起 拡散は小さく，また静的水素浸透の実験結果から長範囲

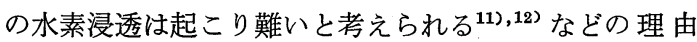
による。

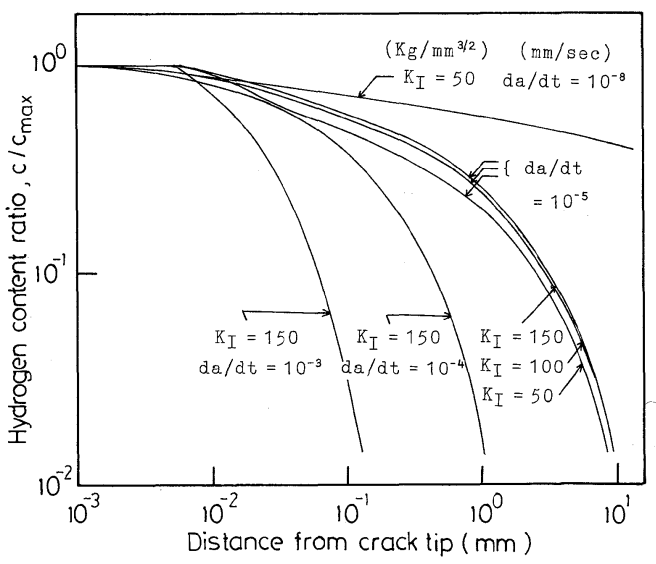

Fig. 4 Hydrogen concentration profiles ahead of moving crack, calculated from eq. (16).

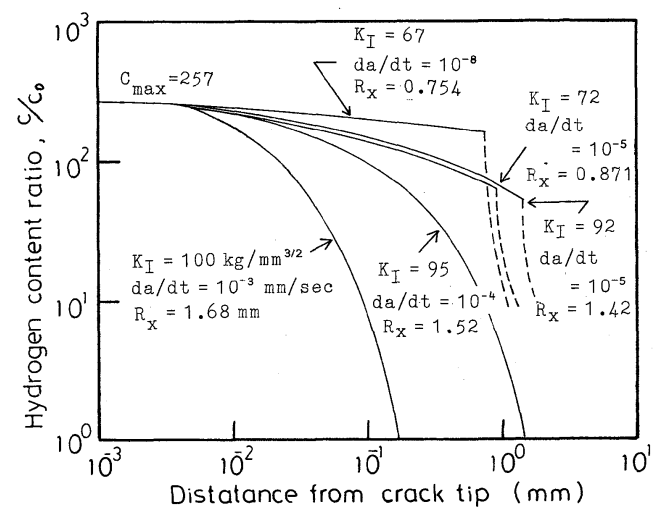

Fig. 5 Hydrogen concentration profiles been suited to the actual behavior of $\mathrm{Al}-8 \% \mathrm{Mg}$ alloy aged at $200^{\circ} \mathrm{C}$ for 1 hour, shown in Fig. 1. Assumed that high concentration of hydrogen is limited to the plastic zone.

領域 I のように $K_{\mathrm{I}}$ が低く $d a / d t$ が小さな場合には塑 性域内で非常に高い水素集積を生じる。 $K_{\mathbf{I}}$ 扝よび $d a / d t$ が増すと濃度の減衰は次第に速くなるが， $K_{\mathrm{I}}$ よりも $d a / d t$ の及ぼす影響の方がより大きいので領域 II ではま だ塑性域内は十分高い濃度を保つている。しかし, 再び $d a / d t$ が急速に増加する領域而では塑性域内に十分水素 が行き渡らなくなる。

水素の集積により合金が脆化する程度はほぼ水素量に 比例している ${ }^{3), 10,, 12)}$ ので，き裂先端 での局部的な材料 強度の変化は $C ! C_{\mathbf{0}}$ の変化に反比例していると考えてよ い。また，応力の分布は $\mathrm{D}$ 領域の先端で最大三軸応力と なるよらな分布をとる ${ }^{21)}$ 。そこで， $K_{I}, d a / d t$ が小さく $C / C_{0}$ の減衰が緩やかな場合と $K_{\mathrm{I}}, d a / d t$ が 大きく $C / C_{0}$ の減衰が速い場合とについて，これらの関係を模式化す るとFig. 6 のよらになる。水素の影響によつて脆性破壊 


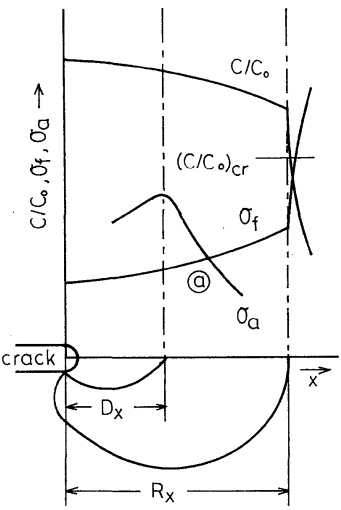

(a)

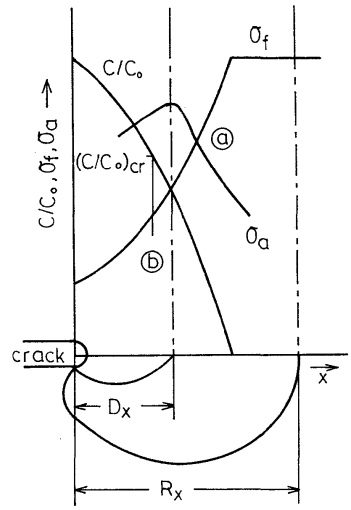

(b)
Fig. 6 Schematic explanation of the crack nucleation based on the hydrogen concentration in the plastic zone.

(a) In the case of low $K_{I}$ and low $d a / d t$. Nucleation of brittle crack can be occurred in a region to the point (a), since a sufficient concentration of hydrogen is realized in the plastic zone.

(b) In the case of high $K_{I}$ and high $d a / d t$. Nucleation of mixed mode crack can be caused by quick decay of hydrogen content.

を生じるには一定の臨界水素濃度が存在すると考えら れるが7，そのレベルを仮に $\left(C / C_{0}\right)_{c r}$ の位置に取るとす る。そらすると, き裂核の発生は材料の局部強度 $\sigma_{f}$ を 負荷応力 $\sigma_{a}$ が上回つた所で生じうるので，Fig. 6 の@ 点以下で可能になる。すなわち, き裂核の発生浪大三 軸応力位置の近傍もしくはそれょり内側で生じる。ま た, Fig. 6(a)のように塑性域内の $C / C_{0}$ が高い場合（領 域 I やII）には脆性き裂が発生することになるが，Fig. 6 (b)のよ5に $C / C_{0}$ が速やかに減衰している場合（領域 III）には(b点以下でのみ脆性き裂の発生が可能であるの で一部延性き裂が混じることになる。

以上の上うな状態にある試験片を引張破壊させると， 脆性破壊するのは $C / C_{0}>\left(C / C_{0}\right)_{c r}$ の範囲であるので, 領域 I やII ぼ塑性域寸法 $R_{x}$ に見合う範囲で脆性破壊し HEZ を形 成する。HEZ の寸法は Fig. 5 から分かるように mmオ ーダーに達し, あまり大きな変化は示さない。実際の破 壊はミク口組織の複雑な影響を受けるので, 観察される HEZ がこの範囲でほぼ一定であるのはその影響と考え られる。一方, 領域亚のように $d a / d t$ が高く $C / C_{0}$ の減 衰が速いと Fig. 6(b)の@点以下でしか脆性破壊しないの で, HEZ は縮小してくる。

なお，Fig. 5 では領域 I，IIの HEZ 寸法は約 $1 \mathrm{~mm}$ となるが，実際のデータ（Fig. 1) は約 $4 \mathrm{~mm}$ である。 これはよく一致しているともいえ, 若干の差異があると
もいえる。これは塑性域寸法の評価法に関係している。

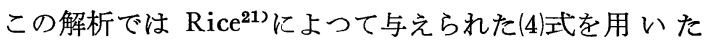

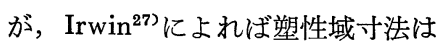

$$
R_{x}^{\prime}=\frac{1}{3 \pi}\left(K_{\mathrm{I}} / \sigma_{y s}\right)^{2}
$$

で表される。たとえば, $K_{\mathrm{I}}=80 \mathrm{~kg} / \mathrm{mm}^{3 / 2}$ とすると Rice の(4)式では $R_{x}=1.08 \mathrm{~mm}$ となるのに対 し, Irwin の(17)式では $R_{x}{ }^{\prime}=3.57 \mathrm{~mm}$ となつて実験值との一致は 一層良くなる。要するに，き裂先端における力学状態の 捕え方の差異に起因した塑性域寸法の表現に関する破壊 力学上の問題が残つており, これの解決されることが必 要である。

\section{4. き裂の伝ぱと特定距離}

発生したき裂核が実際に伝ぱするには別の条件が必要 となる。Knottら ${ }^{28), 291}$ とよればき裂が進展するためには，

$$
D_{x} \geqq X_{0}
$$

なる条件の満足されることが必要とされる。 $X_{0}$ は材料 定数であつて破壊発生に必要な最小領域の大きさと定義 され, 特定距離 (charactersstic distance) と呼ばれてい る。 $X_{0}$ は結晶粒度やき裂核となる第 2 相粒子などとの 関係が検討されているようにミク口組織因子に関係した 材料定数で，き裂核となる第 2 相粒子の平均間隔すなわ ち SZ を打ち切るディンプルの平均間隔に等しいといわ れる ${ }^{28)}$ 。前報7) で示したように HE によつてディンプ ルの平均間隔は小さくなるので, $X_{0}$ も材料の局部的勒性 を反映して変化すると考えられ，発生したき裂が伝ぱす るかどらかは負荷応力によつて形成される $\mathrm{D}$ 領域寸法と $\mathrm{HE}$ によつて変化する $X_{0}$ との兼合いによつて決まるこ とになるはずである。これを模式的に示すとFig. 7 のよ らになる。

領域且のように $K_{\mathbf{I}}$ が高く $d a / d t$ の大きなところで は，Fig. 5 から分かるように十分な $\mathrm{HE}$ を生じている 領域はごく狭く， $D_{x}$ の方が広いと考えられる。この場 合には Fig. 7(a) に示すように, 基本的には通常の延性 破壊に対応する $X_{0(\max )}$ に対して $D_{x}=X_{0(\max )}$ が満足さ れたときにき裂伝ぱが生じることになる。HE 領域より も $D_{x}$ の方が広いので応力支配型の延性破壞が混在する ことになり, HEZ の縮少とその前方の $\mathrm{SZ}$ の増大が 生 じることになる。

$K_{\mathbf{I}}$ と $d a / d t$ が次第に低下し $C / C_{0}$ の減衰が緩やかに なると, HEの影響によつて $X_{0}$ は縮少し，かつ $X_{0}$ 内の $C / C_{0}$ は脆性破壊に必要な臨界水素濃度 $\left(C / C_{0}\right)_{c r}$ を越える ようになる (Fig. $7(\mathrm{~b}))$ 。のとき $D_{x}=X_{0}$ が満足されて 伝ぱするき裂はすべて脆性き裂で，その限界は SCCき 裂の最大速度すなわち領域 II-IIIの境界に当る。 $D_{x}$ は(5) 式で $C T O D$ と関倸付けられ, $C T O D$ と $K_{\mathrm{I}}$ との間には 

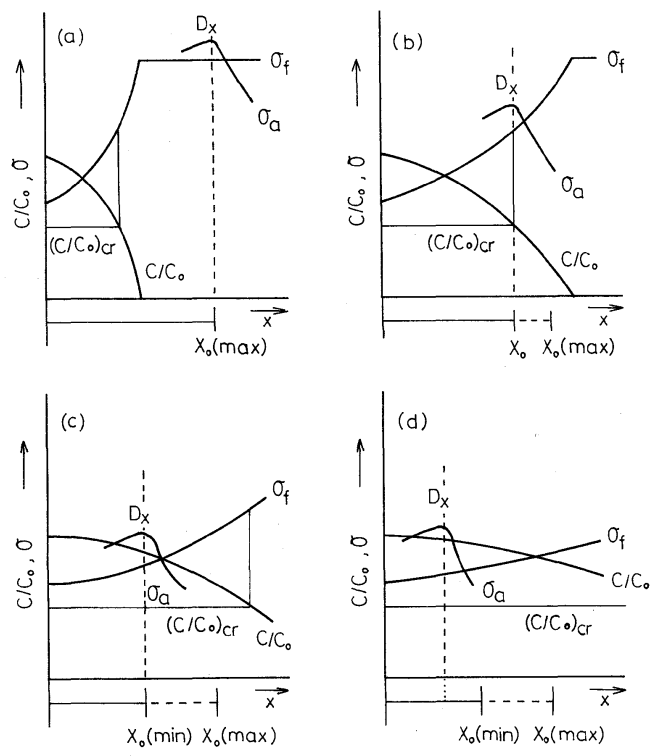

Fig. 7 Schematic explanation of the crack propagation based on the hydrogen embrittlement in the vicinity of crack tip and the relationship between the sizes of D-region and characteristic distance $X_{0}$.

(a) In the case of sufficiently high $K_{I}$ and quick decay of $c / c_{0}$. Mixed mode propagation is occurred.

(b) In the case of intermediate $K_{I}$. If sufficient embrittlement is realized in the region of $X_{0}$ $\left(=D_{x}\right)$, brittle propagation is occurred.

(c) In the case of just at $K_{I S C C}$. The size of $D_{x}$ is equal to the minimized $X_{0}$ caused by the hydrogen effect.

(d) In the case of below $K_{I S C C}$. No propagation is occurred, because the determining condition for propagation $\left(D_{x} \geqq X_{0}\right)$ is not satisfied.

$$
C T O D=\left(1-v^{2}\right) K_{\mathbf{I}}^{2} / \lambda E \sigma_{y s}
$$

なる関係がある。そこで実験データより $K_{\mathrm{II}-\mathrm{III}}=92 \mathrm{~kg} /$ $\mathrm{mm}^{3 / 2}$ で係数 $\lambda=2$ とすれば, (5) (19)式より $D_{x \text { (II-III) }}$ $=75.9 \mu$ となる。これは Table 1に示した本合金の結晶 粒径とほぼ等しい。すなわち，この合金の場合には 1 結 晶粒径以上の範囲で十分な HE を生じたときに SCC き 裂は最も進展しやすくなることを意味するものといえ る。

領域 I， II 範囲では定常的に破壊条件が満足されて いるはずであるから, $D_{x}=X_{0}$ が保たれている。しかし， $X_{0}$ は十分な $\mathrm{HE}$ を生じた状態に対応する最小值 $X_{0(\mathrm{~min})}$ で飽和すると考えられるので， $K_{\mathrm{I}}$ の低下によつて $D_{x}=$ $X_{0(\min )}$ なる状態が現出する (Fig. 7(c))。これ以下の $K_{\mathbf{I}}$ では $D_{x}<X_{0(\min )}$ となり，たとえき裂核が発生したとし ても伝ぱしえない (Fig. 7(d))。すなわち， $D_{x}=X_{0 \text { (min) }}$ なる状態は $K_{\mathrm{ISCC}}$ に対応する。 $X_{0(\mathrm{~min})}$ は HE を生じてい
る材料の脆性き裂進展限界から評価しらるはずであるか ら，これは $\mathrm{HEZ}$ 前方に生じる $\mathrm{SZ}$ より求めることがで きる7 。Fig. 1 に示したように, $S Z W_{(\mathrm{I}, \mathrm{II})}=15 \mu$ であり,

$$
\left.\begin{array}{l}
S Z W=1.5 S Z H^{7)} \\
2 S Z H=C T O D
\end{array}\right\}
$$

であるから，(5) (20)式より $X_{0(\mathrm{~min})}=D_{x}=40.0 \mu$ をう る。これが $\mathrm{HE}$ 状態によつて恋化する $X_{0}$ の下限值 で あり，SCC き裂が伝ぱするには，たとえき裂先端が十 分な $\mathrm{HE}$ を生じていたとしても，少くとも $D_{x}$ が $40 \mu$ 以上に広がる必要のあることを示すものである。ゆえ に，(5) (19)式より $K_{\mathrm{ISCC}}=66.8 \mathrm{~kg} / \mathrm{mm}^{3 / 2}$ となる。これ は実験データと非常によく一致している。

\section{5. 結 論}

本報では Al-8 \% Mg 合金の SCC 挙動を定量的に解 釈するため, 腐食環境中より供給された水素のき裂先端 における集積を応力，ひずみ場との関係で求め， SCCが き裂先端での局部的 $\mathrm{HE}$ に基づいているとして破壞力 学的な考察を加えた。えられた結果を要約すると次のよ らである。

1）水素の集積を応力場による誘起拡散に基づいて求 めると，転位の作る応力場は十分な集積を招き，転 位は有効な水素トラップ源として働くことが分か る。しかし，き裂先端の応力場に適用すると，到達 最大応力が材料の降伏強度に依存するため, 本系合 金のような低い降伏強度をもつ材料では応力場によ る誘起拡散のみでは十分な水素集積を生じえない。

2）そこで，き裂先端での局部的塑性降伏がもたらす 転位密度の増加が水素集積に主要な役割りを果たす と考え, 集積が転位密度の増加に比例すると仮定し てひずみ場の解析より求めると，き裂先端近傍では 非常に高い濃縮の生じらることが明らかとなつた。

3) さらに，SCC 環境中よりの水素の 連続的供給 お よびき裂の移動を考慮すると，濃度分布は負荷 $K_{\mathbf{I}}$ 值とき裂進展速度 $d a / d t$ に依存するが， $K_{\mathbf{I}}$ と $d a / d t$ が小さな場合には塑性域内の水素濃度は非常に高く なる。K $K_{\mathrm{I}}$ が同じであれば $d a / d t$ の増加とともに濃度 分布の減衰は速くなる。一方, $d a / d t$ が同 ごであれ ば $K_{\mathrm{I}}$ の影響は小さい。

4）以上のような解析結果を実際のデータに適合させ ることにより，き裂核の形成は $\mathrm{D}$ 領域先端に生じる 最大三軸応力場の近傍もしくはその内側で可能とな り，また，き裂伝ぱ特性の領域 I や II では塑性域寸 法に見合らような大きな HEZ の形成されらること が分かつた。

5）発生したき裂核が伝ぱするかどうかは負荷応力に よつて形成される D領域寸法 $D_{x}$ と，材料の局部的 
特性によつて決まる特定距離 $X_{0}$ との兼合いによる。 領域而の状態では $\mathrm{D}$ 領域内が十分な $\mathrm{HE}$ を生じて いないので，応力支配型の延性破壊が混在する。領 域 I, II では十分な $\mathrm{HE}$ を生じているので脆性破 壞が生じる。 $K_{\mathrm{ISCC}}$ は $D_{x}$ が $X_{0}$ の最小值 $X_{0(\mathrm{~min})}$ と 一致する状態として特定でき, 計算值と実測值は非 常によい一致を示した。

以上のように， SCC 特性がき裂先端の局部的 HE に 支配されるよらな場合には, 水素濃度分布をひずみ場と 転位とに関倸付けて求め，D領域や特定距離といつた破 壊力学的概念を導入することにより, 定量的に SCC 特 性を評価することが可能であつた。

\section{参 考 文 献}

1) たとえば, A. W. Thompson and I. M. Bernstein:Advances in Corrosion Science and Technology, Vol. 7, Plenum Press, (1980), 53.

2) 大西, 中谷 : 軽金属, 28 (1978) 123.

3) 東, 大西, 中谷, 岡林 : 軽 金 属, 30 (1980) 560 .

4) 大西, 東, 中谷：日本金属学会誌，45 (1981) 373.

5) 東, 大西, 中谷, 岡林 : 軽 金 属, 31 (1981) 386.

6) 東, 大西, 中谷 : 軽金属, 31 (1981) 644 .

7) 大西, 東 : 軽金属. 34 (1984).

8) 大西, 中谷, 坂本 : 軽金属, 26 (1976) 8 .

9) 東, 大西, 中谷, 岡林: 軽 金 属, 30 (1980) 551 .

10）大西，東，井上，中谷 : 日本金属学 会 誌，45 (1981) 972 .

11）大西，原，中谷：軽金属，27(1977) 367.
12）大西，原，毛利，中谷: 軽 金属， 27 (1977) 473.

13) F. H. Haynie and W. K. Boyd: Fundamental Aspects of Stress Corrosion Cracking, NACE, (1969), 580.

14) L. Montgrain and P. R. Swann: Hydrogen in Metals, ASM, (1974), 575.

15) R. A. Oriani: Fundamental Aspects of Stress Corrosion Cracking, NACE, (1969), 32.

16) G. P. Cherepanov: Corrosion, 29 (1973), 305.

17) H. H. Johnson: Hydrogen in Metals, ASM, (1974), 35.

18) H. P. van Leeuwen: Corrosion, 31 (1975), 42.

19) W. W. Gerberich, Y. T. Chen and C. ST. John: Met. Trans., 6 A (1975), 1485.

20) H. Peisl: Hydrogen in Metals, Vol. 1, SpringerVerlag., (1978), 53.

21) J. R. Rice and M. A. Johnson: Inelastic Behavior of Solids, McGraw-Hill, (1970), 641.

22) R. M. McMeeking: J. Mech. Phys. Solids, 25 (1977), 357.

23) J. R. Rice and G. F. Rosengren: J. Mech. Phys. Solids, 16 (1968), 1.

24) C. F. Shih: Fracture Analysis, ASTM STP-560, (1974), 187.

25）鈴木：転位論入門，アグネ，(1967） 89 .

26) H. S. Carslaw and J. C. Jaeger: Conduction of Heat in Solids, Oxford Univ. Press, (1959), 266.

27) G. R. Irwin: Proc. 7th. Sagamore Conf., Syracuse Univ., (1960), IV-63.

28) D. A. Curry and J. F. Knott: Metal, Sci., 10 (1976), 1.

29) J. F. Knott: Advances in Research on the Strength and Fracture of Materials, Vol. 1, Pergamon Press, (1978), 61. 